\title{
Grape pomace silage on growth performance, carcass, and meat quality attributes of
}

\section{lambs}

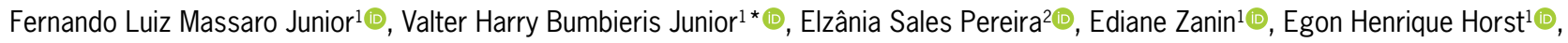

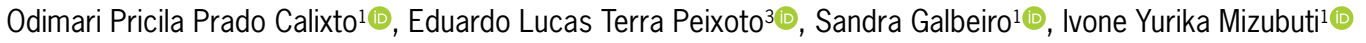

${ }^{1}$ Universidade Estadual de Londrina - Depto. de Zootecnia, Rod. Celso Garcia Cid, km 380 - 86057-970 - Londrina, PR - Brasil.

2Universidade Federal do Ceará - Depto. de Zootecnia, Av. Mister Hull, 2977, Bloco 808 - 60356-000 - Fortaleza, CE - Brasil.

3Universidade Federal da Grande Dourados/FCA, Rod. Dourados/Itahum, km 12, Unidade II - 79804-970 -

Dourados, MS - Brasil.

*Corresponding author <jrbumbieris@uel.br>

Edited by: Melissa Izabel Hannas

Received November 12, 2020

Accepted June 25, 2021
ABSTRACT: Grape pomace is a by-product that can be ensiled and added to animal feed for a sustainable animal production. This study evaluated the effects of grape pomace silage (GPS) on the intake, performance, and carcass and meat quality of feedlot lambs. Twenty-four male lambs $(21.5 \pm 3.0 \mathrm{~kg}$ initial body weight) were distributed into pairs to four diets levels 0,10 , 20 , and $30 \%$ of GPS. The addition of grape pomace silage influenced only ether extract (EE) intake linearly without hindering consumption. The diet did not affect performance and meat quality attributes and carcass parameters, with average daily gain (ADG) of $0.235 \mathrm{~kg} \mathrm{~d}^{-1}$, feed conversion 4.299 , carcass conformation 2.7 , compactness index $0.25 \mathrm{~kg} \mathrm{~cm}^{-1}$, fat thickness

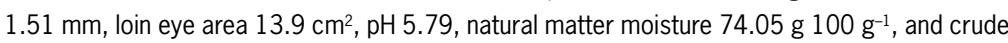
protein (CP) $19.94 \mathrm{~g}$ per $100 \mathrm{~g}^{-1}$ of dry matter (DM). Grape pomace as could be used as silage in lamb diets with up to $30 \% \mathrm{GPS}$, as the chemical composition of this by-product and the results indicate that GPS did not compromise performance, carcass traits, and meat quality.

Keywords: byproduct, conformation, feed conversion, intake, nutrient

\section{Introduction}

Lamb consumption is rising and consumers are more demanding for meat quality standards, which requires production systems to evaluate sheep carcass traits quantitatively and qualitatively (Petrescu et al., 2020). In addition, systems need to be sustainable and adopt actions to preserve environment integrity.

Diets commonly used for ruminants are energy grains that are costly to produce and subject to frequent price fluctuations, besides competing with feeds used in other animal species. Recent studies have suggested partial replacement of grains by agricultural byproducts (Almeida et al., 2019; Mazza et al., 2020; Evan et al., 2020).

The processing of agricultural products generates annually thousands of tons of organic by-products that are rich in seeds, husk, pomace, and pulp with excellent nutrient composition and bioactive compounds that could be used as energy sources. Recently, agro-industrial byproducts have been used in the production of biofuels, antibiotics, biofertilizers, chemicals, enzymes, vitamins, antioxidants, and animal feed (Eleonora et al., 2014; Kodagoda and Marapana, 2017).

Grape pomace is a by-product of the wine industry. It is a low-cost ingredient with good nutritional quality and chemical composition that could be used in animal feed. In addition, grape pomace can be stored as silage (Massaro Junior et al., 2020). The use of grape pomace in different in ruminant diets showed considerable effects on animal growth performance, as well as on carcass and meat quality traits (Gómez-Cortés et al., 2018; Kafantaris et al., 2018; Chikwanha et al., 2019).
Studies have reported effects of grape pomace on animal performance; nevertheless, there is no information on the effects of adding up to $30 \%$ of grape pomace cv. Isabel (Vitis labrusca L.) as silage and limitations of the levels added to lamb diets and the effects of adding GPS on animal performance need investigations. This study investigated the addition of $0,10,20$, and $30 \%$ of grape pomace silage to the diet of feedlot lambs and its effects on nutrient intake, performance, carcass, and meat quality.

\section{Materials and Methods}

\section{Experiment and animal handling}

The study was carried out in the municipality of Londrina, Panará State, Brazil $\left(23^{\circ} 20^{\prime} 23^{\prime \prime}\right.$ S, 51 ${ }^{\circ} 12^{\prime} 32^{\prime \prime}$ W, altitude $580 \mathrm{~m})$. The Ethics Committee on Animal Experiments approved the study under the identification number (Protocol $n^{\circ} 78 / 10$ ). The experiment comprised 24 male lambs of mixed breed with approximately four months of age with an initial average live weight of $21.5 \pm 3.0 \mathrm{~kg}$. The animals were wormed and identified before the study. The experimental design was completely randomized with four treatments and three replications, and the pen was a repetition. The lambs were distributed in pairs and housed in pens provided with troughs and drinkers for 21 days for adaptation to the diets, to the experiment, and to the facilities, followed by a 35-day trial period. The animals were slaughtered with an average live weight of $33.81 \pm 2.85$ $\mathrm{kg}$ and average carcass weight of $15 \mathrm{~kg}$, according to consumer acceptance. 
The animal were weighed at the beginning and end of the adaptation period and every 15 days during the experimental period. Prior to slaughter, the animals were weighed after $16 \mathrm{~h}$ of fasting to calculate final weight, average daily weight gain (ADG), and feed conversion. ADG was obtained by the ratio between weight gain and number of feedlot days, while feed conversion was obtained by the ratio between total feed intake and weight gain during the feedlot period.

The ration was provided in two meals with $50 \%$ each of diet total at $7 \mathrm{~h} 30 \mathrm{a} . \mathrm{m}$. and $4 \mathrm{~h} 30 \mathrm{p} . \mathrm{m}$. and adjusted to provide $15 \%$ of dry matter (DM) at ad libitum. DM and nutrient intake were calculated by subtracting from feed amount provided.

\section{Experimental diets}

Grape pomace was obtained from the juice industry in Paraná State, Brazil, shortly after processing. The byproduct evaluated came from grapes $\mathrm{cv}$. Isabel (Vitis labrusca L.) and was largely composed of seeds $610 \mathrm{~g} \mathrm{~kg}^{-1}$ $\mathrm{DM})$, peels, and pulp residues (390 $\left.\mathrm{g} \mathrm{kg}^{-1} \mathrm{DM}\right)$. At the time of collection, the by-product was $11 \% \mathrm{DM}$ and was dehydrated outdoors and turned over three times a day, until reaching approximately $30 \% \mathrm{DM}$. The by-product was then treated with $5 \mathrm{~g} \mathrm{~kg}^{-1}$ natural matter (NM) of urea and ensiled in 100- and 200-liter plastic drums stored for seven months until the beginning of the experiment. The sorghum used for silage production was cultivated under a no-tillage system at the university farm and the sorghum was stored in a bunker silo after cutting.

Four isoproteic $\left(160.46 \pm 0.21 \mathrm{~g} \mathrm{~kg}^{-1} \mathrm{DM}\right.$ of $\left.\mathrm{CP}\right)$ and isoenergetic $\left(674.85 \pm 5.23 \mathrm{~g} \mathrm{~kg}^{-1} \mathrm{DM}\right.$ of TDN) diets were used. Grape pomace silage (GPS) was included at $0,10,20$, and $30 \%$ of the dry base, maintaining the bulk concentrated ration of 55:45 (Table 1). The TDN contents of the feed formulation ingredients were estimated according to the equations proposed by Kearl (1982).

The ration samples were provided and $20 \%$ of the leftovers were collected weekly directly from the trough. We analyzedthe contents of dry matter (DM), organic matter $(\mathrm{OM})$, crude protein $(\mathrm{CP})$, and ether extract (EE), according to the methodologies described in AOAC (1990). The neutral detergent insoluble fiber (NDF) was analyzed according to Van Soest (1963) (Table 1). Total carbohydrates (TCHO) and nonfibrous carbohydrates (NFC) were calculated according to equations proposed by Sniffen et al. (1992).

\section{Evaluation of carcass traits}

The animals were weighed and then subjected to 16 $\mathrm{h}$ of solid fasting and then weighed again to obtain body weight at slaughter (BWS). During this period, the animals were transported to the slaughterhouse under municipal inspection at $7 \mathrm{~h} 00$ a.m. with a specific collective stall truck, equipped with a railing floor and a bed of rice straw, following the transportation rules
Table 1 - Chemical composition of ingredients and experimental diets.

\begin{tabular}{|c|c|c|c|c|}
\hline Chemical ingredients ( $\mathrm{g} \mathrm{kg}^{-1} \mathrm{DM}$ ) & Corn & Soybean meal & SS & GPS \\
\hline Dry matter ( $\mathrm{g} \mathrm{kg}^{-1}$ natural matter) & 885.6 & 897.9 & 278.6 & 305.9 \\
\hline Organic matter & 984.8 & 935.0 & 924.0 & 959.9 \\
\hline Crude protein & 90.1 & 505.9 & 58.4 & 139.8 \\
\hline Ether extract & 37.5 & 14.8 & 16.5 & 83.4 \\
\hline Crude fiber & 25.0 & 55.3 & 359.9 & 420.5 \\
\hline Neutral detergente fiber & 163.6 & 166.4 & 691.4 & 640.7 \\
\hline Acid detergente fiber & 37.0 & 68.5 & 438.3 & 533.1 \\
\hline Total carbohydrates & 823.5 & 818.2 & 533.2 & 679.3 \\
\hline Non-fibrous carbohydrates & 857.2 & 414.3 & 849.1 & 736.7 \\
\hline Total digestible nutrients & 693.6 & 247.9 & 157.7 & 96 \\
\hline DIVDM & - & - & - & 461.2 \\
\hline $\begin{array}{l}\text { Percent composition of diets } \\
\left(\mathrm{g} \mathrm{kg}^{-1} \mathrm{DM}\right)\end{array}$ & \multicolumn{4}{|c|}{ Inclusion of GPS (\%) } \\
\hline & 0 & 10 & 20 & 30 \\
\hline SS & 550.0 & 495.0 & 440.0 & 385.0 \\
\hline GPS & 0.0 & 55.0 & 110.0 & 165.0 \\
\hline Corn & 240.0 & 250.0 & 260.0 & 270.0 \\
\hline Soybean meal & 210.0 & 200.0 & 190.0 & 180.0 \\
\hline Total & 1000.0 & 1000.0 & 1000.0 & 1000.0 \\
\hline \multicolumn{5}{|l|}{ Chemical diets ( $\left.\mathrm{g} \mathrm{kg}^{-1} \mathrm{DM}\right)$} \\
\hline Dry matter ( $\mathrm{g} \mathrm{kg}^{-1}$ natural matter) & 554.3 & 555.7 & 571.1 & 558.5 \\
\hline Organic matter & 940.9 & 943.4 & 945.8 & 948.3 \\
\hline Crude protein & 160.0 & 160.3 & 160.6 & 160.9 \\
\hline Ether extract & 21.2 & 25.1 & 29.0 & 32.9 \\
\hline Neutral detergente fiber & 454.5 & 451.6 & 448.8 & 446.0 \\
\hline Acid detergente fiber & 264.3 & 269.2 & 274.1 & 279.0 \\
\hline Total carbohydrates & 759.7 & 758 & 756.2 & 754.4 \\
\hline Non-fibrous carbohydrates & 305.3 & 306.4 & 307.4 & 308.4 \\
\hline Total digestible nutrients & 662.7 & 670.8 & 678.9 & 687.0 \\
\hline
\end{tabular}

proposed by the Ministry of Agriculture, Livestock and Supply (MAPA, 2017). The animals were slaughtered with stunning by the percussive method using a pneumatic pistol, followed by bleeding, skinning, and evisceration, according to the rules established in the Brazilian Regulation for Industrial and Sanitary Inspection of Products of Animal Origin (MAPA, 2017).

The carcasses were identified, weighed to determine the hot carcass weight (HCW), and cooled in cold rooms at $2{ }^{\circ} \mathrm{C}$. Then, the carcasses were weighed and after $24 \mathrm{~h}$ of cooling at $2{ }^{\circ} \mathrm{C}$, the cold carcass weight (CCW) was obtained. Hot $(\mathrm{HC})$ and cold $(\mathrm{CC})$ carcass yields were calculated by the percentages of hot and cold carcass weights in relation to the final weight (FW) and cooling weight loss (CWL) by the difference between the two carcass weights according to Osório and Osório (2005).

The gastrointestinal tract was collected, weighed full and empty, and the difference was used to obtain the weight of the gastrointestinal content used to determine the empty live weight (ELW) and true yield (TY), where: ELW = WG - weight of gastrointestinal 
content and $\mathrm{TY}=((\mathrm{HCW} / \mathrm{ELW}) \times 100)$. The carcass compactness index (CCI) was calculated according to Cezar and Souza (2007), where: CCI $\left(\mathrm{kg} \mathrm{cm}^{-1}\right)=\mathrm{CCW} /$ cold carcass internal length.

After cooling, conformation (values from 1 concave to 6 - convex), finishing (values from 1 - cover fat absent to 5 - abundant cover fat) and cover fat were evaluated using photographic standards (Cañeque and Sañudo, 2001). We also measured carcass length and chest depth, length, perimeter and leg and arm depths (Osório and Osório, 2005).

The left half carcasses were sectioned at the $12^{\text {th }}$ rib height to assess the loin eye area (LEA), fat thickness, depth and width of the longissimus thoracis et lumborum (LTL) muscle according to Cezar and Souza (2007). The marbling rate was subjectively evaluated using photographic standards from the American Meat Science Association - AMSA (2001), with grades ranging from 1 to $10(1=$ marbling traces and $10=$ abundant marbling).

The spine was boned to obtain the LTL muscle. The muscle was divided into portions: three portions for shear force (3-cm thickness for each), one portion for color measurements, the $\mathrm{pH}$, marbling and drip water loss (2-cm thickness), one portion for proximate analysis, (2-cm thick) and a portion for lipid oxidation index (2-cm thickness).

The shear force samples were obtained from two to three separate portions of the LTL muscle of each animal, depending on the piece size, according to AOAC (1990). Ten samples of each portion were taken and cooked to an internal temperature of $71{ }^{\circ} \mathrm{C}$ and seven subsamples measuring approximately $1.25 \mathrm{~cm}$ thick and $2.5 \mathrm{~cm}$ long were obtained from these samples using a cylindrical steel sampler (Whipple et al., 1990).

The shear force was measured in the seven subsamples using the 3-mm blade shear probe attached to the Brookfield ${ }^{\circledR}$ CT3 Texture Analyzer texturometer. A trained observer evaluated color of $\mathrm{L}^{*}$ (brightness), a * (red-green component) and b* (yellow-blue component) components as described by Miltenburg et al. (1992). The colorimeter was set to the $L^{*}, a^{*}, b^{*}$ system and illuminant D65, observer angle of $2^{\circ}$, aperture size of $5.0 \mathrm{~mm}$, and a closed cone. These values were used to calculate the hue angle $\left(\mathrm{h}^{*}\right)$ by the equation $\mathrm{h}^{*}=$ $\tan -1\left(b^{*} / a^{*}\right)$ and the saturation index, or chroma $\left(\mathrm{c}^{*}\right)$, from the equation $\mathrm{c}^{*}=\left(2 \mathrm{a}^{*}+2 \mathrm{~b}^{*}\right) 0.5$ following the methodology of MacDougall and Taylor (2007).

Drip water loss was evaluated according to the technique described by Boccard (1981) by cooling at $4{ }^{\circ} \mathrm{C}$ for $48 \mathrm{~h}$. The $\mathrm{pH}$ was checked inside the cold chamber of the refrigerator at a temperature of $2{ }^{\circ} \mathrm{C}$ using a portable potentiometer with a Testo ${ }^{\circledR} 205$ insertion electrode equipped with a temperature sensor, which was previously calibrated. The left palette was frozen and subsequently dissected to obtain the bone, muscle, and fat proportion, according to the methodology of Fisher and Boer (1994).
For the lipid oxidation index, the 2-thiobarbituric acid test (TBARS) was performed, weighing $5 \mathrm{~g}$ of homogenized sample and adding $25 \mathrm{~mL}$ of $7.5 \%$ tetramethoxypropane. Subsequently, homogenization was performed for $1 \mathrm{~min}$ with corning tube filtration. We added $4 \mathrm{~mL}$ of the filtrate, $1 \mathrm{~mL}$ of trichloroacetic acid, and $5 \mathrm{~mL}$ of thiobarbituric acid to the test tube. The tubes were placed in a boiling water bath for 45 min. After cooling, a spectrophotometer reading at $538 \mathrm{~nm}$ was performed followed by a standard curve, according to the method described by Cherian et al. (2002).

\section{Statistical analysis}

The data were submitted to the Shapiro-Wilk and Bartlett tests to verify the assumptions of normality and homogeneity of variance, respectively. After meeting these assumptions, the data were submitted to the analysis by the mixed procedure (PROC MIXED) including the treatment as a fixed effect and the stall as a random effect. Significance was determined at the level of 0.05 according to the Tukey test of comparison of multiple means by the SAS program (v. 9.2; SAS Institute Inc., Cary, NC), following the model:

$Y_{i j}=\mu+\alpha_{i}+\beta_{i j}+\varepsilon_{i j}$

where: $\mathrm{Y}_{\mathrm{ij}}=$ Variable response related to treatment $\mathrm{i}$ in pen $j_{i} \mu=$ Overall average; $\alpha_{i}=$ Effect of treatment $i_{\text {; }}$ $\beta_{\mathrm{ij}}=$ Effect of treatment $\mathrm{i}$ in pen $\mathrm{j} ; \varepsilon_{\mathrm{ij}}=$ Random error associated with each $\mathrm{Y}_{\mathrm{ij}}$ observation.

All data on nutrient intake and performance were analyzed by the Regression procedure (PROC REG). When applicable, the regression models were chosen by their degree of adjustment $\left(R^{2}\right)$.

\section{Results}

\section{Nutrient intake and performance}

GPS in the diet increased only EE daily consumption linearly $(p<0.05)$ (Table 2). ADG and FC were not influenced ( $p>0.05$ ) by GPS in the diet (Table 3), with an average value ADG of $235.2 \pm 13.07 \mathrm{~g} \mathrm{~d}^{-1} \mathrm{~kg}$ and FC of 4.299 . The inclusion of $10 \%$ GPS increased the final body weight lambs by $3.6 \%$ than the control group. Lambs fed with $20 \%$ of GPS obtained $9.4 \%$ more ADG than the control group and the best FC among all treatments; however, difference in performance was not significant.

\section{Carcass traits and meat quality}

GPS did not influence $(p>0.05)$ the carcass traits of lambs (Table 4) nor carcass biometric measurements and bone, muscle, fat yield in the palette, as well as the index carcass compactness (Table 5). 
Table 2 - Consumption of nutrients in confined lambs fed diets containing different levels of inclusion GPS.

\begin{tabular}{|c|c|c|c|c|c|c|c|c|}
\hline \multirow{3}{*}{ Consumption } & \multicolumn{4}{|c|}{ Inclusion of GPS (\%) } & \multirow{2}{*}{ Equation } & \multirow{2}{*}{$\mathrm{R}^{2}$} & \multirow{2}{*}{$p$-value } & \multirow{2}{*}{ CV } \\
\hline & 0 & 10 & 20 & 30 & & & & \\
\hline & \multicolumn{8}{|c|}{ Dry matter } \\
\hline $\mathrm{g} \mathrm{d}^{-1}$ & $1038.4 \pm 10.41$ & $950.3 \pm 108.43$ & $974.8 \pm 113.55$ & $1039.4 \pm 52.45$ & 1000.7 & - & 0.68 & 10.78 \\
\hline g kg Body weigth $0.75 \mathrm{~d}^{-1}$ & $82.42 \pm 6.29$ & $79.61 \pm 6.63$ & $76.40 \pm 7.60$ & $82.80 \pm 7.87$ & 80.31 & - & 0.76 & 10.18 \\
\hline \multirow[t]{2}{*}{$\%$ Body weigth $\mathrm{d}^{-1}$} & $3.54 \pm 0.26$ & $3.49 \pm 0.39$ & $3.27 \pm 0.31$ & $3.56 \pm 0.40$ & 3.47 & - & 0.78 & 11.18 \\
\hline & \multicolumn{8}{|c|}{ Crude protein } \\
\hline $\mathrm{g} \mathrm{d}^{-1}$ & $177.0 \pm 5.98$ & $171.4 \pm 16.94$ & $177.2 \pm 8.71$ & $187.9 \pm 24.60$ & 178.3 & - & 0.65 & 8.75 \\
\hline g kg Body weight ${ }^{0.75} \mathrm{~d}^{-1}$ & $14.07 \pm 0.34$ & $14.44 \pm 2.08$ & $13.90 \pm 0.59$ & $14.96 \pm 2.24$ & 14.34 & - & 0.80 & 9.99 \\
\hline \multirow[t]{2}{*}{$\%$ Body weigth $\mathrm{d}^{-1}$} & $0.61 \pm 0.02$ & $0.63 \pm 0.11$ & $0.60 \pm 0.03$ & $0.64 \pm 0.10$ & 0.62 & - & 0.82 & 11.82 \\
\hline & \multicolumn{8}{|c|}{ Ether extract } \\
\hline $\mathrm{g} \mathrm{d}^{-1}$ & $26.2 \pm 2.39$ & $28.2 \pm 4.54$ & $32.7 \pm 7.13$ & $41.8 \pm 0.13$ & $\hat{Y}=24.56+0.51 x$ & 0.67 & 0.01 & 13.13 \\
\hline g kg Body weight ${ }^{0.75} \mathrm{~d}^{-1}$ & $2.08 \pm 0.16$ & $2.36 \pm 0.26$ & $2.56 \pm 0.53$ & $3.32 \pm 0.18$ & $\hat{Y}=1.99+0.039 x$ & 0.69 & 0.02 & 13.57 \\
\hline \multirow[t]{2}{*}{$\%$ Body weight $d^{-1}$} & $0.09 \pm 0.01$ & $0.10 \pm 0.01$ & $0.11 \pm 0.02$ & $0.14 \pm 0.01$ & $\hat{Y}=0.087+0.0015 x$ & 0.61 & 0.04 & 14.76 \\
\hline & \multicolumn{8}{|c|}{ Neutral detergent insoluble fiber } \\
\hline $\mathrm{g} \mathrm{d}^{-1}$ & $260.1 \pm 56.23$ & $228.5 \pm 46.08$ & $222.6 \pm 50.23$ & $269.5 \pm 23.29$ & 245.1 & - & 0.53 & 18.01 \\
\hline g kg Body weight ${ }^{0.75} \mathrm{~d}^{-1}$ & $20.59 \pm 3.98$ & $18.95 \pm 1.72$ & $17.41 \pm 3.54$ & $21.50 \pm 2.92$ & 19.61 & - & 0.45 & 15.90 \\
\hline \multirow[t]{2}{*}{$\%$ Body weight $\mathrm{d}^{-1}$} & $0.88 \pm 0.17$ & $0.83 \pm 0.05$ & $0.74 \pm 0.15$ & $0.93 \pm 0.14$ & 0.85 & - & 0.43 & 15.87 \\
\hline & \multicolumn{8}{|c|}{ Non-fibrous carbohydrates } \\
\hline $\mathrm{g} \mathrm{d}^{-1}$ & $509.6 \pm 34.98$ & $461.4 \pm 46.18$ & $479.34 \pm 43.18$ & $477.70 \pm 15.13$ & 482.01 & - & 0.49 & 7.66 \\
\hline g kg Body weight $0.75 \mathrm{~d}^{-1}$ & $40.48 \pm 1.94$ & $38.75 \pm 4.18$ & $37.59 \pm 2.91$ & $38.03 \pm 2.75$ & 38.71 & - & 0.74 & 9.54 \\
\hline \multirow[t]{2}{*}{$\%$ Body weight $\mathrm{d}^{-1}$} & $1.70 \pm 0.09$ & $1.61 \pm 0.12$ & $1.64 \pm 0.15$ & $1.63 \pm 0.15$ & 1.65 & - & 0.68 & 7.89 \\
\hline & \multicolumn{8}{|c|}{ Total digestible nutrients } \\
\hline $\mathrm{g} \mathrm{d}^{-1}$ & $667.4 \pm 66.00$ & $595.2 \pm 67.46$ & $614.2 \pm 72.77$ & $645.8 \pm 32.02$ & 630.6 & - & 0.60 & 10.81 \\
\hline g kg Body weight ${ }^{0.75} \mathrm{~d}^{-1}$ & $52.98 \pm 3.97$ & $49.88 \pm 4.28$ & $48.14 \pm 4.89$ & $51.44 \pm 4.84$ & 50.61 & - & 0.70 & 10.23 \\
\hline$\%$ Body weight $d^{-1}$ & $2.28 \pm 0.17$ & $2.19 \pm 0.25$ & $2.06 \pm 0.20$ & $2.21 \pm 0.25$ & 2.19 & - & 0.75 & 11.32 \\
\hline
\end{tabular}

Values are mean \pm standard error of the means. GPS $=$ Grape pomace silage; CV = Coefficient of variation.

Table 3 - Performance of confined lambs, fed diets containing different levels of inclusion GPS.

\begin{tabular}{lccccrrr}
\hline \multirow{2}{*}{ Variables } & \multicolumn{4}{c}{ Inclusion of GPS (\%) } & \multirow{2}{*}{ Average } & \multirow{2}{*}{$p$-value } & \multirow{2}{*}{ CV } \\
\cline { 2 - 5 } & 0 & 10 & 20 & 30 & & \\
\hline Initial body weight, $\mathrm{kg}$ & $25.33 \pm 1.94$ & $26.23 \pm 1.18$ & $25.43 \pm 0.77$ & $25.25 \pm 1.80$ & $25.56 \pm 1.34$ & 0.87 & 6.38 \\
Final body weight, $\mathrm{kg}$ & $33.27 \pm 2.20$ & $34.45 \pm 0.48$ & $34.16 \pm 1.54$ & $33.35 \pm 2.08$ & $33.81 \pm 1.56$ & 0.84 & 5.68 \\
ADG, $\mathrm{g} \mathrm{d}^{-1}$ & $226.7 \pm 0.01$ & $234.8 \pm 0.04$ & $248.1 \pm 0.04$ & $231.4 \pm 0.01$ & $235.2 \pm 0.03$ & 0.78 & 12.10 \\
Feed Conversion & $4.642 \pm 0.07$ & $4.080 \pm 0.27$ & $3.810 \pm 0.92$ & $4.664 \pm 0.07$ & $4.299 \pm 0.56$ & 0.12 & 9.98 \\
\hline
\end{tabular}

Values are mean \pm standard error of the means; GPS $=$ Grape pomace silage; $A D G=$ Average daily gain; Feed conversion $=\mathrm{kg} \mathrm{DM} \mathrm{kg}^{-1} \mathrm{ADG} G P M D ; C V=C$ eefficient of variation.

Muscle LTL and meat quality did not vary $(p>$ 0.05 ) due to GPS in the diets (Table 6). Mean values of $1.51 \pm 43.93 \mathrm{~mm}$ of fat thickness were observed. The compactness index of $0.25 \mathrm{~kg} \mathrm{~cm}^{-1}$ indicated good muscle proportion and an average marbling score of 1.64. The loin eye area was $13.9 \mathrm{~cm}^{2}$, the meat $\mathrm{pH}$ was 5.79 , and the shear force obtained was 33 N. GPS had no influence $(p>0.05)$ on the centesimal composition of the LTL muscle (Table 7).

\section{Discussion}

\section{Nutrient intake and performance}

The GPS levels increased; therefore, EE intake rose linearly (Table 2), which may be related to the diet chemical composition that increased EE in $\mathrm{g} \mathrm{kg}^{-1} \mathrm{DM}$, as GPS alone had a higher EE content than the other ingredients (Table 1). Chikwanha et al. (2018) also observed a positive linear relationship between EE intake and inclusion level of GPS to the diets. The increased EE content in the GPS diet is due to the higher density of seeds (610 $\left.\mathrm{g} \mathrm{kg}^{-1} \mathrm{DM}\right)$, which have a higher oil concentration (Shinagawa et al., 2015) than the peel and pulp (390 $\left.\mathrm{g} \mathrm{kg}^{-1} \mathrm{DM}\right)$. In our work, the quality of GPS cv. Isabel (Vitis labrusca L.) showed higher EE content, due to seed density (Massaro Junior et al., 2020). GuerraRivaz et al. (2017) also found that the proportion of seeds in grape pomace ranged from 406 to $564 \mathrm{~g} \mathrm{~kg}^{-1}$ DM and higher EE in seeds than in pulp (31.7 vs $99.0 \mathrm{~g}$ $\left.\mathrm{kg}^{-1} \mathrm{DM}\right)$. Therefore, the linear increase of EE intake can be explained by the higher EE concentration in the GPS, which increased EE concentration in the diet due to the higher GPS levels added (Table 2). 
Table 4 - Carcass characteristics of confined lambs fed with diets containing different levels of inclusion GPS.

\begin{tabular}{|c|c|c|c|c|c|c|c|}
\hline \multirow{2}{*}{ Variables } & \multicolumn{4}{|c|}{ Inclusion of GPS (\%) } & \multirow{2}{*}{ Average } & \multirow{2}{*}{$p$-value } & \multirow{2}{*}{ CV } \\
\hline & 0 & 10 & 20 & 30 & & & \\
\hline Final live weight, kg & $33.3 \pm 3.68$ & $34.5 \pm 0.92$ & $34.1 \pm 3.31$ & $33.9 \pm 2.11$ & $33.9 \pm 2.63$ & 0.90 & 8.22 \\
\hline Empty live weight, kg & $28.3 \pm 3.39$ & $29.2 \pm 0.93$ & $29.2 \pm 3.18$ & $29.0 \pm 1.84$ & $28.9 \pm 2.43$ & 0.93 & 8.93 \\
\hline Hot carcass weight, $\mathrm{kg}$ & $15.0 \pm 2.20$ & $15.4 \pm 0.70$ & $15.2 \pm 1.66$ & $15.3 \pm 1.06$ & $15.2 \pm 1.43$ & 0.98 & 10.05 \\
\hline Cold carcass weight, $\mathrm{kg}$ & $14.4 \pm 2.14$ & $14.7 \pm 0.66$ & $14.5 \pm 1.67$ & $14.7 \pm 1.06$ & $14.6 \pm 1.41$ & 0.97 & 10.32 \\
\hline $\mathrm{HCY}, \mathrm{kg} 100 \mathrm{~kg}^{-1}$ of carcass & $45.0 \pm 1.97$ & $44.6 \pm 1.31$ & $44.6 \pm 1.74$ & $45.3 \pm 1.77$ & $44.9 \pm 1.60$ & 0.88 & 3.77 \\
\hline $\mathrm{CCY}, \mathrm{kg} 100 \mathrm{~kg}^{-1}$ of carcass & $43.0 \pm 1.95$ & $42.7 \pm 1.31$ & $42.6 \pm 1.84$ & $43.4 \pm 1.88$ & $42.9 \pm 1.66$ & 0.86 & 4.07 \\
\hline TY, kg $100 \mathrm{~kg}^{-1}$ of carcass & $52.9 \pm 2.12$ & $52.7 \pm 1.20$ & $52.1 \pm 1.33$ & $52.8 \pm 1.90$ & $52.6 \pm 1.62$ & 0.85 & 3.25 \\
\hline LC, $\mathrm{kg} 100 \mathrm{~kg}^{-1}$ of carcass & $4.4 \pm 0.28$ & $4.2 \pm 0.35$ & $4.4 \pm 0.69$ & $4.1 \pm 0.52$ & $4.3 \pm 0.48$ & 0.74 & 11.55 \\
\hline FGT, kg & $7.8 \pm 0.84$ & $8.0 \pm 0.69$ & $7.8 \pm 0.58$ & $7.6 \pm 0.68$ & $7.8 \pm 0.68$ & 0.80 & 9.15 \\
\hline EGT, kg & $2.8 \pm 0.42$ & $2.7 \pm 0.20$ & $2.9 \pm 0.20$ & $2.8 \pm 0.16$ & $2.8 \pm 0.26$ & 0.83 & 9.73 \\
\hline Carcass conformation & $2.9 \pm 0.49$ & $2.8 \pm 0.38$ & $2.5 \pm 0.63$ & $2.6 \pm 0.86$ & $2.7 \pm 0.60$ & 0.64 & 22.86 \\
\hline Carcass finishing & $2.8 \pm 0.52$ & $2.8 \pm 0.38$ & $2.5 \pm 0.63$ & $2.6 \pm 0.86$ & $2.7 \pm 0.59$ & 0.76 & 23.25 \\
\hline
\end{tabular}

Values are mean \pm standard error of the means. GPS $=$ Grape pomace silage; $\mathrm{CV}=$ Coefficient of variation; $\mathrm{HCY}=$ Hot carcass yield; $\mathrm{CCY}=\mathrm{Cold}$ carcass yield; TY = true yield; $\mathrm{LC}=$ Loss by cooling; FGT = full gastrointestinal content; EGT = empty gastrointestinal content; 1 ( 1 concave -6 convex); 2 ( 1 absent- 5 abundant).

Table 5 - Biometric measurements $(\mathrm{cm})$ and palette yield of confined lambs fed diets containing different levels of inclusion GPS.

\begin{tabular}{|c|c|c|c|c|c|c|c|}
\hline \multirow{2}{*}{ Carcass characteristics } & \multicolumn{4}{|c|}{ Inclusion of GPS (\%) } & \multirow{2}{*}{ Average } & \multirow{2}{*}{$p$-value } & \multirow{2}{*}{ CV } \\
\hline & 0 & 10 & 20 & 30 & & & \\
\hline Carcass length & $57.5 \pm 2.07$ & $58.4 \pm 1.52$ & $61.2 \pm 4.07$ & $58.6 \pm 2.07$ & $58.9 \pm 2.87$ & 0.14 & 4.55 \\
\hline Thoracic depth & $25.7 \pm 1.51$ & $24.8 \pm 0.89$ & $25.3 \pm 1.03$ & $26.0 \pm 0.63$ & $25.5 \pm 1.08$ & 0.32 & 4.17 \\
\hline Shank length & $39.8 \pm 2.02$ & $38.0 \pm 1.58$ & $38.3 \pm 1.04$ & $40.2 \pm 1.21$ & $39.1 \pm 1.65$ & 0.06 & 3.74 \\
\hline Perimeter of shank & $39.6 \pm 2.06$ & $39.1 \pm 1.07$ & $39.6 \pm 1.69$ & $38.6 \pm 2.40$ & $39.2 \pm 1.80$ & 0.76 & 4.78 \\
\hline Depth of shank & $9.9 \pm 0.67$ & $9.6 \pm 0.80$ & $9.8 \pm 0.94$ & $9.7 \pm 0.96$ & $9.8 \pm 0.81$ & 0.94 & 8.91 \\
\hline Arm length & $18.9 \pm 1.20$ & $18.7 \pm 1.11$ & $18.3 \pm 0.41$ & $19.0 \pm 0.80$ & $18.7 \pm 0.82$ & 0.45 & 4.42 \\
\hline Perimeter of arm & $18.0 \pm 1.18$ & $18.5 \pm 0.45$ & $18.3 \pm 0.94$ & $18.0 \pm 0.84$ & $18.2 \pm 0.88$ & 0.76 & 5.04 \\
\hline Depth of arm & $6.2 \pm 0.20$ & $6.0 \pm 0.29$ & $6.0 \pm 0.34$ & $6.0 \pm 0.20$ & $6.1 \pm 0.27$ & 0.31 & 4.34 \\
\hline Compactness Index, $\mathrm{kg} \mathrm{cm}^{-1}$ & $0.2 \pm 0.03$ & $0.3 \pm 0.01$ & $0.2 \pm 0.03$ & $0.3 \pm 0.02$ & $0.25 \pm 0.02$ & 0.77 & 9.87 \\
\hline Bone, $\mathrm{kg} 100 \mathrm{~kg}^{-1}$ of palette & $22.5 \pm 1.71$ & $23.2 \pm 3.10$ & $23.0 \pm 1.32$ & $22.9 \pm 1.73$ & $22.9 \pm 1.96$ & 0.95 & 9.16 \\
\hline 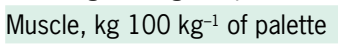 & $62.9 \pm 1.32$ & $61.1 \pm 2.56$ & $62.5 \pm 2.34$ & $62.4 \pm 2.80$ & $62.2 \pm 2.27$ & 0.64 & 3.76 \\
\hline Fat, kg $100 \mathrm{~kg}^{-1}$ palette & $14.6 \pm 1.17$ & $15.7 \pm 4.24$ & $14.5 \pm 2.46$ & $14.6 \pm 3.00$ & $14.9 \pm 2.84$ & 0.90 & 20.28 \\
\hline
\end{tabular}

Values are mean \pm standard error of the means. GPS $=$ Grape pomace silage; $\mathrm{CV}=$ Coefficient of variation.

The values for nutrient intake due to GPS addition in our study (Table 2) are in agreement with Chikwanha et al. (2019) and Zhao et al. (2018). The authors suggest that nutrient intake not was influenced by GPS inclusion. Chikwanha et al. (2019) found a DMI increase of up to $11.3 \%$ with GPS inclusion in lamb diet and considered GPS an alternative feed to replace fiber sources rich in polyphenolic compounds to reduce feeding costs and improve performance and carcass characteristics. Although sheep have a significant selective capacity and the proportion of seeds is greater than the other GPS components, there were no leftovers from the diets with up to $30 \%$ GPS inclusion, with GPS accounting for $165 \mathrm{~g} \mathrm{~kg}^{-1} \mathrm{DM}$ in the total diet. The average DMI (3.5\% live weight) met the requirements of the animals and presented a value according with NRC (2007), that is, $3.5 \%$ for the animal category analyzed with $30 \mathrm{~kg}$ and ADG 300 $\mathrm{g} \mathrm{d}^{-1}$, recommended by Mertens (1987) for ruminant animals (1.2\% of live weight); thus, the NDFI in our study is close to this recommendation.

Gao et al. (2019) evaluated the inclusion of up to $15 \%$ of GPS in lamb diets and found lower DMI and NDFI values with higher levels of GPS added. In our work, DMI and NDFI values showed no difference (Table 2) with inclusion up to $30 \%$ of GPS in the diet, indicating that palatability was not negatively affected by adding GPS of cultivar Isabel Vitis Labrusca L. The GPS addition can be limited because due to high tannin content in seeds, which can have negative effects on nutrient digestion and palatability. However, some benefits are observed, such as alteration rumen fermentation and microbial protein synthesis, depending on the level, type, and nature of tannins (Gao et al., 2019).

The performance of feedlot lambs was not influenced by diets containing different levels of GPS. The results for ADG and FC in this study are considered satisfactory, when compared to data from other studies 
Table 6 - Parameters of the LTL muscle in confined lambs fed diets containing different levels of inclusion GPS.

\begin{tabular}{|c|c|c|c|c|c|c|c|}
\hline \multirow{2}{*}{ Variables } & \multicolumn{4}{|c|}{ Inclusion of GPS (\%) } & \multirow{2}{*}{ Average } & \multirow{2}{*}{$p$-value } & \multirow{2}{*}{$\mathrm{CV}^{\mathrm{c}}$} \\
\hline & 0 & 10 & 20 & 30 & & & \\
\hline Fat thickness, mm & $1.46 \pm 0.89$ & $1.66 \pm 0.57$ & $1.60 \pm 0.65$ & $1.30 \pm 0.47$ & $1.51 \pm 0.63$ & 0.80 & 43.93 \\
\hline Depth of muscle, mm & $52.59 \pm 4.75$ & $51.70 \pm 3.64$ & $53.84 \pm 3.35$ & $52.69 \pm 3.03$ & $52.71 \pm 3.48$ & 0.81 & 6.92 \\
\hline Muscle width, mm & $28.12 \pm 2.77$ & $29.73 \pm 2.56$ & $27.85 \pm 3.40$ & $28.91 \pm 2.73$ & $28.65 \pm 2.76$ & 0.70 & 10.01 \\
\hline Loin eye area, $\mathrm{cm}^{2}$ & $14.17 \pm 1.94$ & $14.60 \pm 0.84$ & $13.33 \pm 1.37$ & $13.50 \pm 1.76$ & $13.90 \pm 1.55$ & 0.52 & 11.32 \\
\hline Marbling & $1.50 \pm 0.84$ & $1.40 \pm 0.52$ & $2.17 \pm 1.17$ & $1.50 \pm 0.84$ & $1.64 \pm 0.88$ & 0.45 & 53.84 \\
\hline LWD, g $100 \mathrm{~g}^{-1}$ & $3.12 \pm 0.69$ & $2.97 \pm 0.34$ & $3.01 \pm 0.77$ & $3.10 \pm 0.58$ & $3.05 \pm 0.57$ & 0.97 & 20.07 \\
\hline LWT, g 100 g$^{-1}$ & $5.65 \pm 2.22$ & $5.50 \pm 2.50$ & $4.94 \pm 2.50$ & $6.06 \pm 1.40$ & $5.54 \pm 1.99$ & 0.83 & 37.78 \\
\hline LWC, g $100 \mathrm{~g}^{-1}$ & $22.66 \pm 5.94$ & $21.12 \pm 5.25$ & $22.29 \pm 3.33$ & $17.72 \pm 2.78$ & $20.95 \pm 4.76$ & 0.27 & 22.11 \\
\hline $\mathrm{pH}$ & $5.77 \pm 0.07$ & $5.86 \pm 0.12$ & $5.80 \pm 0.14$ & $5.73 \pm 0.17$ & $5.79 \pm 0.13$ & 0.44 & 2.20 \\
\hline Shear force, $\mathrm{N}$ & $35.7 \pm 0.78$ & $32.3 \pm 0.44$ & $32.4 \pm 0.62$ & $31.4 \pm 0.63$ & $33.0 \pm 0.61$ & 0.66 & 19.18 \\
\hline Lipid oxidation, mg TBA, kg & $0.30 \pm 0.06$ & $0.38 \pm 0.11$ & $0.32 \pm 0.04$ & $0.37 \pm 0.11$ & $0.34 \pm 0.09$ & 0.38 & 25.58 \\
\hline$L^{*}$ & $40.29 \pm 1.28$ & $38.71 \pm 1.76$ & $40.34 \pm 1.54$ & $39.55 \pm 2.79$ & $39.72 \pm 1.91$ & 0.49 & 4.85 \\
\hline$a^{*}$ & $13.88 \pm 1.36$ & $13.73 \pm 1.79$ & $14.67 \pm 1.16$ & $15.54 \pm 1.54$ & $14.46 \pm 1.57$ & 0.18 & 10.30 \\
\hline$b^{*}$ & $9.29 \pm 0.70$ & $8.69 \pm 0.68$ & $9.45 \pm 0.93$ & $9.43 \pm 1.43$ & $9.22 \pm 0.99$ & 0.58 & 10.93 \\
\hline c & $16.71 \pm 1.41$ & $16.26 \pm 1.77$ & $17.45 \pm 1.44$ & $18.22 \pm 1.73$ & $17.16 \pm 1.68$ & 0.23 & 9.41 \\
\hline $\mathrm{h}^{\circ}$ & $33.88 \pm 1.91$ & $32.49 \pm 2.61$ & $32.76 \pm 1.25$ & $31.22 \pm 3.77$ & $32.59 \pm 2.58$ & 0.38 & 7.88 \\
\hline
\end{tabular}

Values are mean \pm standard error of the means. GPS $=$ Grape Pomace Silage; CV $=$ Coefficient of variation; LWD $=$ Loss of water by dripping; LWT $=$ Loss of water by thawing; $L W C=$ Loss of water by cooking; $L^{*}=$ lightness; $a^{*}=$ red intensity; $b^{*}=$ yellow intensity; $c=$ croma; $h=$ hue.

Table 7 - Proximate composition of the LTL muscle of confined lambs fed diets containing different levels of inclusion GPS.

\begin{tabular}{|c|c|c|c|c|c|c|c|}
\hline \multirow{2}{*}{ Item } & \multicolumn{4}{|c|}{ Inclusion of GPS (\%) } & \multirow{2}{*}{ Average } & \multirow{2}{*}{ p-value } & \multirow{2}{*}{$\mathrm{CV}$} \\
\hline & 0 & 10 & 20 & 30 & & & \\
\hline \multicolumn{8}{|c|}{ g $100 g^{-1}$ DM } \\
\hline Moisture & $74.36 \pm 2.09$ & $74.85 \pm 0.60$ & $73.54 \pm 1.49$ & $73.45 \pm 1.43$ & $74.05 \pm 1.53$ & 0.38 & 5.84 \\
\hline Ash & $0.90 \pm 0.12$ & $0.89 \pm 0.11$ & $0.87 \pm 0.06$ & $0.85 \pm 0.05$ & $0.88 \pm 0.07$ & 0.74 & 8.81 \\
\hline Protein & $19.52 \pm 3.10$ & $19.33 \pm 1.41$ & $19.91 \pm 1.18$ & $21.00 \pm 1.30$ & $19.94 \pm 1.84$ & 0.44 & 9.24 \\
\hline Lipids & $4.97 \pm 1.48$ & $4.34 \pm 0.80$ & $5.81 \pm 1.96$ & $4.43 \pm 1.03$ & $4.89 \pm 1.42$ & 0.29 & 28.35 \\
\hline
\end{tabular}

Values are mean \pm standard error of the means. GPS $=$ Grape pomace silage; $\mathrm{CV}=$ Coefficient of variation.

on GPS addition to lamb diets (Chikwanha et al., 2019; Kafantaris et al., 2018; Zhao et al., 2018; Gómez-Cortés et al., 2018). Calderón-Cortés et al. (2018) assessed the replacement of alfalfa by up to $30 \%$ dehydrated grape by-product and did not observe variation in lamb performance, with ADG of 106.0 g. Zhao et al. (2018) found greater ADG and lower feed: gain ratio with the addition of 5 and $10 \%$ of GPS in lamb diets than in the group control, with 177.9 and $215.3 \mathrm{~g} \mathrm{~d}^{-1} \mathrm{~kg}$ ADG and 8.1 and 6.9 of feed: gain ratio, respectively, indicating that this diet improved the feed efficiency. In our study, the average values of $235.2 \mathrm{~g} \mathrm{~d}^{-1} \mathrm{~kg}$ ADG and FC of 4.299 showed that GPS addition is a considerable ingredient for lamb diets.

Kafantaris et al. (2018) also observed better performance of lambs fed with a GPS-added diet and reported that the ADG significantly increased before weaning compared to the control group. These researchers suggested that GPS may be included to the diet of growing lambs with considerable economic benefits to growers and production. GPS may also benefit performance due to its antioxidant properties that eliminate reactive oxygen species (ROS); thereby, reducing membrane damage and consequently improving intestinal functionality and reducing pathogenic microorganisms (Kafantaris et al., 2017).

\section{Carcass traits and meat quality}

The average values of final live weight and hot and cold carcass weight were similar to results obtained by Zhao et al. (2018) when supplementing lambs with up to $10 \%$ grape marc. Gómez-Cortés et al. (2018) and Chikwanha et al. (2019) found similar average carcass yield by adding grape marc to lamb diets. Hot and cold carcass yields showed average values considered satisfactory in agreement with values found in the literature for GPS-added diets (Kafantaris et al., 2018; Gómez-Cortés et al., 2018).

Chikwanha et al. (2019) also found values close to three for conformation for lamb diets with GPS addition. The average finish rate may be due to animal age and the method used for skinning. Fat coverage may have favored higher cooling loss values than the values observed by Oliveira et al. (2018) for Santa Inês lambs, since fat deposition reflects cooling loss, higher fat content leads to less water loss during cooling, due to its protective function, preventing losses and improving meat tenderness (Sañudo et al., 2000). 
The animals in our study were homogeneous, that is, with same ages, weights, and sex and were supplied with rations of similar nutritional value, which may have contributed to the similarity in biometric evaluations and bone, muscle and fat composition, and the compactness index. This similarity indicates that the animals showed the same degree of body development. The average value obtained for the compactness index of $0.25 \mathrm{~kg}$ $\mathrm{cm}^{-1}$ indicates good muscle proportion and is between 0.15 and $0.28 \mathrm{~kg} \mathrm{~cm}^{-1}$ for animals of different genotypes (Figueiredo et al., 2015).

The LTL muscle had average values for fat thickness of $1.51 \mathrm{~mm}$, close to values found by Calderón-Cortés et al. (2018) for lambs fed with dried grape pomace. Fat thickness may be related to animal age and the skinning method. According to Ponnampalam et al. (2007), young animals have reduced fat deposition in the carcass and lean meat than old sheep. However, the average shear force values were $33 \mathrm{~N}$ and a slight lower value was observed for lambs fed with a GPS-added diet. Zhao et al. (2018) also observed a reduced value for lambs fed with grape pomace compared the control group. Chikwanha et al. (2019) reported shear force values below $49 \mathrm{~N}$ for lambs fed diets with grape pomace.

The average LEA value was $13.9 \mathrm{~cm}^{2}$, close to the average values of 11.40 and $13.07 \mathrm{~cm}^{2}$ obtained by Souza Júnior et al. (2013) in lambs of large and medium frame size kept in feedlot. According to Bastos et al. (2015), the average LEA values for Santa Inês lambs are between 9.6 and $14.8 \mathrm{~cm}^{2}$. The addition of GPS to the diets showed no significant difference on LEA; thus, carcasses possibly showed similarity of muscularity (Table 6) due to the nonsignificance of diets on the yield and carcass, cuts, and the compactness index (Table 5). The average score of 1.64 obtained for marbling in the LTL muscle indicates little deposition of intramuscular fat in the carcass of lambs. Lonergan et al. (2019) reported that the intramuscular fat deposition occurs later than other the adipose tissue deposition in the animal and that intramuscular fat deposition occurs at a more advanced age of the growth process, justifying the low value obtained for marbling in our study.

Color is the most important characteristic to indicate freshness and quality for consumers at the time of product purchase (Van Ooijen et al., 2017). The average value 14.46 obtained for redness values in our study exceeds the threshold value of $\geq 9.5$, considered acceptable by lamb meat consumers (Khliji et al., 2010). The values for color red intensity and other constituents are close to those found in the literature (Chikwanha et al., 2019; Figueiredo et al., 2015). For Zhao et al. (2017), the darker pigmentation in general in lamb masks any kind of color improvement, regardless of the diet. For the shear force, $49 \mathrm{~N}$ is an acceptable sensitivity in sheep meat (Hopkins et al., 2006), we found lower values in our study.

The mean $\mathrm{pH}$ value obtained in carcasses $24 \mathrm{~h}$ postmortem is within the acceptable range for sheep carcasses (Majdoub-Mathlouthi et al., 2013). Drip losses, defrosting, and meat cooking were not influenced by the GPS contents in the diets. This result was possibly influenced by the absence of dietary interference on $\mathrm{pH}$, marbling, and finishing parameters. The meat centesimal composition was not influenced by diet and the values observed are close to those reported in the literature with grape pomace added to lamb diets (Chikwanha et al., 2019; Gómez-Cortés et al., 2018). GPS used in our study can be considered to be an alternative feed for lamb diets, considering the chemical composition of this by-product and results indicating that GPS did not compromise performance, carcass traits, and meat quality.

Our data suggest that the GPS levels of cultivar Isabel (Vitis Labrusca L.) increased linearly the EE intake, without affecting consumption. The DWG and FC showed were satisfactory results, with good muscle proportion and carcass conformation. The traits evaluated show that up to $30 \%$ GPS can be added to lamb diets. In addition, this approach provides sheep meat production with sustainable resources that meet the demands of consumers.

\section{Acknowledgments}

We wish to thank the graduate program in Animal Science of the State University of Londrina (Londrina, Paraná, Brazil), the financial support from Araucaria Foundation and Coordination for the Improvement of Higher Level Personnel (CAPES, Brasília, Brazil).

\section{Authors' Contributions}

Conceptualization: Massaro Junior, F.L.; Bumbieris Junior, V.H.; Mizubuti, I.Y. Data acquisition: Massaro Junior, F.L. Data analysis: Horst, E.H.; Peixoto, T.L.E. Design of methodology: Pereira, E.S.; Calixto, P.P.O.; Galbeiro, S. Writing and editing: Massaro Junior, F.L.; Zanin, E.

\section{References}

Almeida, J.C.S.; Figueiredo, D.M.; Azevedo, K.K.; Paixão, M.L.; Ribeiro, E.G.; Dallago, G.M. 2019. Intake, digestibility, microbial protein production, and nitrogen balance of lambs fed with sorghum silage partially replaced with dehydrated fruit by-products. Tropical Animal Health and Production 51: 619-627.

American Meat Science Association. [AMSA]. 2001. Meat Evaluation Handbook. National Cattlemen's Beef Association. Savoy, IL, USA.

Association of Official Analytical Chemists - International [AOAC]. 1990. Official Methods of Analysis. 17ed. AOAC, Arlington, VA, USA.

Bastos, M.P.V.; Carvalho, G.G.P.; Pires, A.J.V.; Silva, R.R.; Carvalho, B.M.A.; Brandão, K.C.; Maranhão, A.C.M. 2015. Impact of total substitution of corn for soybean hulls in diets for lambs. Revista Brasileira de Zootecnia 44: 83-91. 
Boccard, R.; Buchter, L.; Casteels, E.; Cosentino, E.; Dransfield, E.; Hood, D.; Touraille, C. 1981. Procedures for measuring meat quality characteristics in beef production experiments. Report of a Working Group in the Commission of the European Communities' Beef Production Research Programme. Livestock Production Science 8: 385-397.

Calderón-Cortés, J.F.; González-Vizcarra, V.M.; Pétriz-Celaya, Y.; Pujol, L.C.; Barreras, A.; Plascencia, A. 2018. Energy value of unfermented dried grape pomace as substitute of alfalfa hay in diets for growing lambs. Austral Journal of Veterinary Sciences 63: 59-63.

Cañeque, V.; Sañudo, C. 2001. Methodology for the Study of the Quality of the Carcass and Meat in Ruminants = Metodología para el Estudio de la Calidad de la Canal y de la Carne en Ruminantes. Instituto Nacional de Investigación y Tecnologia y Alimenticia, Madrid, Spain (in Spanish).

Cezar, M.F.; Souza, W.H. 2007. Sheep and Goat Carcasses: Production, Evaluation and Classification = Carcaças Ovinas e Caprinas: Obtenção, Avaliação e Classificação. Agropecuária Tropical, Uberaba, MG, Brazil (in Portuguese).

Cherian, G.; Selvaraj, R.K.; Goeger, M.P.; Stitt, P.A. 2002. Muscle fatty acid composition and thiobarbituric acid-reactive substances of broilers fed different cultivars of sorghum. Poultry Science 81: 1415-20.

Chikwanha, O.C.; Raffrenato, E.; Muchenje, V.; Musarurwa, H.T.; Mapiye, C. 2018. Varietal differences in nutrient, amino acid and mineral composition and in vitro rumen digestibility of grape (Vitis vinifera) pomace from the Cape Winelands vineyards in South Africa and impact of preservation techniques. Industrial Crops and Products 118: 30-37.

Chikwanha, O.C.; Muchenjeb, V.; Noltec, E.J.; Dugand, E.R.M.; Mapiye, C. 2019. Grape pomace (Vitis vinifera L. cv. Pinotage) supplementation in lamb diets: effects on growth performance, carcass and meat quality. Meat Science 147: 6-12.

Eleonora, N.; Dobrei, A.; Dobrei, A.; Bampidis, V.; Ciolac, V. 2014. Grape pomace in sheep and dairy cows feeding. Journal of Horticulture, Forestry and Biotechnology 18: 146-150.

Evan, T.; Cabezas, A.; Fuente, J.; Carro, M.D. 2020. Feeding agroindustrial by products to light lambs: influence on growth performance, diet digestibility, nitrogen balance, ruminal fermentation, and plasma metabolites. Animals10: 600.

Figueiredo, M.D.; Almeida, S.J.C.; Boari, A.C.; Paixão, L.M.; Sena, B.A.J.; Barbosa, L.J.; Ortêncio, O.M.; Moreira, F.K. 2015. Performance, body measurements, carcass and cut yields, and meat quality in lambs fed residues from processing agroindustry of fruits. Semina Ciências Agrárias 36: 541-556.

Fisher, A.V.; Boer, H. 1994. The EAAP standard method of sheep carcass assessment. Livestock Production Science 38: 149-159.

Gao, X.; Tang, F.; Zhang, F.; Jia, C.; Yang, Z.; Liu, C.; Gao, W. 2019. Effects of the supplementation of distillers' grape residues on ruminal degradability, whole tract digestibility and nitrogen metabolism in sheep. Archives of Animal Nutrition 73: 1-15.

Gómez-Cortés, P.; Guerra-Rivas, C.; Gallardo, B.; Lavín, P.; La Fuente, M.A.; Mantecón Manso, T. 2018. Grape pomace in ewes diet: effects on meat quality and the fatty acid profile of their suckling lambs. Food Research International 113: 36-42.
Guerra-Rivas, C.; Gallardo, B.; Mantecón, Á.R.; Del ÁlamoSanza, M.; Manso, T. 2017. Evaluation of grape pomace from red wine by-product as feed for sheep. Journal of the Science of Food and Agriculture 97: 1885-1893.

Hopkins, D.L.; Hegarty, R.S.; Walker, P.J.; Pethick, D.W. 2006. Relationship between animal age, intramuscular fat, cooking loss, $\mathrm{pH}$, shear force and eating quality of aged meat from sheep. Australian Journal of Experimental Agriculture 46: 879884 .

Kafantaris, I.; Kotsampasi, B.; Christodoulou, V.; Kokka, E.; Kouka, P.; Terzopoulou, Z.; Gerasopoulos, K.; Stagos, D.; Mitsagga, C.; Giavasis, I.; Makri. S.; Petrotos, K.; Kouretas, D. 2017. Grape pomace improves antioxidant capacity and fecal microflora of lambs. Journal of Animal Physiology and Animal Nutrition 101: 108-121.

Kafantaris, I.; Kotsampasi, B.; Christodoulou, V.; Makri, S.; Stagos, D.; Gerasopoulos, K.; Petrotos, K.; Goulas, P.; Kouretas, D. 2018. Effects of dietary grape pomace supplementation on performance, carcass traits and meat quality of lambs. In vivo 32: 807-812.

Kearl, L.C. 1982. Nutrient Requirements of Ruminants in Developing Countries. Utah Agriculture Experimental Station, Logon, UT, USA.

Khliji, S.; Van de Ven, R.; Lamb, T.A.; Lanza, M.; Hopkins, D.L. 2010. Relationship between consumer ranking of lamb color and objective measures of color. Meat Science 85: 224-229.

Kodagoda, K.H.G.K.; Marapana, R.A.U.J. 2017. Utilization of fruit processing by-products for industrial applications: a review. International Journal of Food Science and Nutrition 2: 24-30.

Lonergan, M.S.; Topel, G.D.; Marple, N.D 2019. Fat and fat cells in domestic animals. p. 51-69. In: Lonergan, M.S.; Topel, G.D.; Marple, N.D., eds. The science of animal growth and meat technology. 2ed. Academic Press, New York, NY, USA.

MacDougall, D.B.; Taylor, A.A. 2007. Colour retention in fresh meat stored in oxygen-a commercial scale trial. International Journal of Food Science \& Technology 10: 339-347.

Majdoub-Mathlouthi, L.; Saïd, B.; Say, A.; Kraiem, K. 2013. Effect of concentrate level and slaughter body weight on growth performances, carcass traits and meat quality of Barbarine lambs fed oat hay based diet. Meat Science 93: 557-563.

Massaro Junior, F.L.; Bumbieris Junior, V.H.; Zanin, E.; Silva, L.D.F.; Galbeiro, S.; Pereira, E.S.; Neumann, M.; Mizubuti, I.Y. 2020. Effect of storage time and use of additives on the quality of grape pomace silages. Journal Food Processing and Preservation 44: e14373.

Mazza, P.H.S.; Jaeger, S.M.P.L.; Silva, F.L.; Barbosa, A.M.; Nascimento, T.V.C.; Hora, D.I.C.; Oliveira, R.L. 2020. Effect of dehydrated residue from acerola (Malpighia emarginata DC.) fruit pulp in lamb diet on intake, ingestive behavior, digestibility, ruminal parameters and $\mathrm{N}$ balance. Livestock Science 233: 103938.

Mertens, D.R. 1987. Predicting intake and digestibility using mathematical models of ruminal function. Journal of Dairy Science 64: 1548-1558.

Miltenburg, G.A.; Wensing, T.; Smulders, F.J.; Breukink, H.J. 1992. Relationship between blood hemoglobin, plasma and tissue iron, muscle heme pigment, and carcass color of veal. Journal Animal Science 70: 2766-72. 
Ministério da Agricultura, Pecuária e Abastecimento [MAPA]. 2017. Regulation of Industrial and Sanitary Inspection of Products of Animal Origin = Regulamento da Inspeção Industrial e Sanitária de Produtos de Origem Animal (RIISPOA). MAPA, Brasília, DF, Brazil (in Portuguese).

National Research Council [NRC]. 2007. Nutrient Requirements of Small Ruminants: Sheep, Goats, Cervids, and New World Camelids. NRC, Washington, DC, USA.

Oliveira, F.G.; Sousa, W.H.; Cartaxo, F.Q.; Cunha, M.G.G.; Ramos, J.P.F.; Cezar, M.F.; Menezes, L.M.; Oliveira, A.B. 2018. Carcass characteristics of Santa Ines sheep with different biotypes and slaughtering weights. Revista Brasileira de Saúde e Produção Animal 19: 347-359.

Osório, J.C.S.; Osório, M.T.M. 2005. Sheep Meat Production: In Vivo and Carcass Evaluation Techniques = Produção de Carne Ovina: Técnicas de Avaliação in Vivo e na Carcaça. 2ed. UFPEL, Pelotas, RS, Brazil (in Portuguese).

Petrescu, D.C.; Vermeir, I.; Petrescu-Mag, R.M. 2020. Consumer understanding of food quality, healthiness, and environmental impact: a cross-national perspective. International Journal of Environmental Research and Public Health 17: 169.

Ponnampalam, E.N.; Hopkins, D.L.; Dunshea, F.R.; Pethick, D.W.; Butler, K.L.; Warner, R.D. 2007. Genotype and age effects on sheep meat production. 4. Carcass composition predicted by dual energy X-ray absorptiometry. Australian Journal of Experimental Agriculture 47: 1172.

Sañudo, C.; Alfonso, M.; Sánchez, A.; Delfa, R.; Teixeira, A. 2000. Carcass and meat quality in lambs from different fat classes in the EU carcass classification system. Meat Science 56: 89-94.

Shinagawa F.B.; Santana F.C.; Torres L.R.O.; Mancini-Filho, J. 2015. Grape seed oil: a potential functional food. Food Science and Technology 35: 399-406.
Sniffen, C.J.; O'Connor, J.D.; Van Soest, P.J.; Fox, D.G.; Russell, J.B. 1992. A net carbohydrate and protein availability. Journal of Animal Science 70: 3562-3577.

Souza Júnior, E.L.; Sousa, W.H.; Pimenta Filho, E.C.; Gonzaga Neto, S.; Cartaxo, F.Q.; Cezar, M.F.; Cunha, M.G.G.; Pereira Filho, J.M. 2013. Effect of frame size on performance and carcass traits of Santa Inês lambs finished in a feedlot. Revista Brasileira de Zootecnia 42: 284-290.

Whipple, G.; Koohmaraie, M.; Dikeman, M.E.; Crouse, J.D. 1990. Predicting beef-longissimus tenderness from various biochemical and histological muscle traits. Journal of Animal Science 68: 4193-4199.

Van Ooijen, I.; Fransen, M.L.; Verlegh, P.W.J.; Smit, E.G. 2017. Packaging design as an implicit communicator: effects on product quality inferences in the presence of explicit quality cues. Food Quality and Preference 62: 71-79.

Van Soest, P.J. 1963. User of detergents in the analyses of fibrous feeds. II. A rapid method for the determination of fibers and lignin. Journal of Association of Official Analytical Chemists 46: 829-835.

Zhao, J.; Li, K.; Su, R.; Liu, W.; Ren, Y.; Zhang, C.; Zhang, J. 2017. Effect of dietary Tartary buckwheat extract supplementation on growth performance, meat quality and antioxidant activity in ewe lambs. Meat Science 134: 79-85.

Zhao, J.X.; Li, Q.; Zhang, R.X.; Liu, W.Z.; Ren, Y.S.; Zhang, C.X.; Zhang, J.X. 2018. Effect of dietary grape pomace on growth performance, meat quality and antioxidant activity in ram lambs. Animal Feed Science and Technology 236: 76-85. 